\title{
MAHRAM FOR WOMEN HAJJ PILGRIMS: Analysis of 'illat and Development of Mahram Meaning
}

\author{
Busyro', Ismail'2, Fajrul Wadi3, Adlan Sanur Tarihoran'4, Edi Rosman' \\ 1,2,3, 4, 5 State Institute for Islamic Studies (IAIN) Bukittinggi, Indonesia \\ Jl. Raya Bukittinggi-Kubang Putih, Sumatera Barat 26181 \\ E-mail: 'busyro.pro18@gmail.com; 2ismanov_2003@yahoo.com; 3fajrulwadi74@gmail.com; ${ }^{4 a d l a n s a n u r @ g m a i l . c o m ; ~}$ \\ 5edirosman@gmail.com
}

\begin{abstract}
Discussion of the obligations of mahram for women in carrying out the pilgrimage has been discussed since the period of classical scholars to modern age. In fact, for women the pilgrimage is a means of jihad for them. Various thoughts have been put forward by scholars to interpret the Hadith about mahram, starting from textual understanding, which still requires mahram, to the discovery of 'illat. This last understanding leads to the conclusion that having mahram is no longer necessary because the security as 'illat can be realized. It is in this connection that this paper aims to compromise between textual understanding and the study of 'illat so that it can be a solution for women pilgrims. This study used a descriptive analytical method with 'illat study approach. The results showed that security for women pilgrims can be realized by using the meaning of mahram in terms of language, namely people who are forbidden to marry each other, so that fellow women is also a mahram. Therefore, their departure together with other women can realize the demands of nash without leaving nash textually.
\end{abstract}

Keywords: mahram; women; contemporary; 'illat; security.

\begin{abstract}
Abstrak:Perbincangan kewajiban mahram bagi perempuan dalam melaksanakan perjalanan haji sudah dibicarakan sejak periode ulama klasik sampai kontemporer. Bahkan, bagi seorang perempuan ibadah haji merupakan sarana jihad bagi mereka. Berbagai pemikiran dikemukakan oleh ulama untuk memaknai hadis tentang mahram, mulai dari pemahaman tekstual, yang masih tetap mewajibkan bermahram, sampai kepada penemuan 'illat. Pemahaman terakhir ini membawa kepada kesimpulan bahwa bermahram tidak diperlukan lagi karena keamanan sebagai 'illat sudah dapat direalisasikan. Dalam kaitan inilah tulisan ini bertujuan mengkompromikan antara pemahaman tekstual dengan kajian 'illat agar bisa menjadi solusi bagi jamaah haji perempuan. Penelitian ini menggunakan metode deskripstif analitis dengan pendekatan kajian 'illat. Hasil penelitian menunjukkan bahwa keamanan bagi jamaah haji perempuan dapat terealisir dengan menggunakan makna mahram dari segi bahasa, yaitu orang-orang yang haram saling menikah, maka sesama perempuan juga termasuk mahram. Oleh karena itu kepergian mereka bersama-sama dengan perempuan lainnya sudah dapat merealisasikan tuntutan nash tanpa meninggalkan nash secara tekstual.
\end{abstract}

Kata kunci: mahram; perempuan; kontemporer; 'illat; keamanan.

\section{Introduction}

Mahram is an important component discussed by the Prophet PBUH when regulating a woman's journey. That is what is read in the various Hadiths of the Prophet concerning it. The provisions regarding the prohibition of travel for a woman were conveyed by the Prophet explicitly and clearly, although in some Hadiths it is stated with certain distances, but in others there is no distance limit. This means that this provision is something that is clear and has been mentioned over and over again.
The journey of a woman, with the need to be accompanied by a mahram, is not only on an ordinary journey, but also on an obligatory journey such as a pilgrimage. This of course also means that a woman is not allowed to travel, even if it is a pilgrimage, if she is not accompanied by her mahram. Of course, this provision will also contradict other traditions which say that the pilgrimage is a means of jihad for women. If only because of the lack of a mahram, it would be rationally impossible to restrict women from 
gaining their jihad fields. However, these are the existing arguments, which seem to contradict one another.

With regard to the mahram during the pilgrimage of a woman, Islamic law scholars have actually discussed this with various opinions which are divided in principle into three groups. First, scholars who remain firm in practicing the Hadith prohibiting traveling without a mahram absolutely, this group is represented by Imâm Ahmad ibn Hanbal' and Imâm Abû Hanîfah. ${ }^{2}$ Second, the scholars who study these Hadiths are based on the underlying 'illat and enforce the Hadiths according to the 'illat they find, and this group is represented by Imâm Mâlik and Imâm al-Syâfi'î. ${ }^{3}$ Meanwhile, the third group, the ulama who absolutely allow it because it relates to the provisions of the Quranic verse in general and as a means of jihad for women, this group is represented by ibn Hazm from the Zhahiri school of thought. ${ }^{4}$ Even ibn Hazm said that the mahram is the duty of men to facilitate it, not the duty of women. If a woman goes on pilgrimage without a mahram, then it is not the woman who is sinning, but the man who did not prepare the mahram for her. ${ }^{5}$ Mecca, since they have to bear more costs to fulfill the mahram obligations as contained in the Hadith. ${ }^{6}$

When connected with the current modern conditions, with gender issues and movements in progressive Islam that do not accept the differences between men and women in various life activities, then enforcing the rules in the Hadith will feel burdensome and seem gender

${ }^{1}$ Ibn Qudâmah, al Mughnî, (Mesir: Maktabah al Jumhûriyyah al 'Arabiyyah, [tth]), vol. 3, p. 235; 'Abd al Qadîr ibn Umar al Syaibâni wa Ibrâhîm ibn Muhammad Dhiwânî, Al-Mu'tamad fî Fiqh al Imâm Ahmad, (Beirut: Dâr al Khair, 1991), vol. 1, p. 327.

2 Kamâl al Dîn Muhammad ibn al Wâhid al Sayuâsi ibn al Humâm al Hanafî, Syarah Fath al Qadîr, (Beirut: Dâr al-Fikr, [tth]), vol. 2, p. 419.

${ }^{3}$ Abû Zakariâ Muhyi al Dîn al Nawawî, Al Majmû' Syarh al Mudhadzdzab, (Kairo: Syirkah al-Azhar, [tth]), vol. 7, p. 86.

${ }^{4}$ Abû Muhammad Ibn Sa'îd ibn Hazm, Al Muhallâ, (Beirut: Dâr al-Fikr, [tth]), vol. 4, pp. 50-1.

${ }^{5}$ Faqihuddin Abdul Khair, "Metode Interpretasi Teks-Teks Agama Dalam Mazhab Salafi Saudi Mengenai Isu-Isu Gender", vol. 13, no. 2 (2012), p. 159.

${ }^{6}$ Atiyatul Ulya and Maulana, "Penyertaan Mahram Pada Pelaksanaan Haji Dan Umrah”, Refleksi, vol. 15, no. 2 (2016), p. 198. biased. For progressive Islamic activists, one of the themes that is believed is that the theme of gender equality has been emphasized in Islam.? Such regulations do not place them as God's creatures who have the same rights as men in all matters, ${ }^{8}$ including worship. ${ }^{9}$ For this reason, the existence of these traditions will be highly questioned and possibly rejected because they are no longer suitable for this era. Therefore, this paper will try to find a middle way so that these traditions are not abandoned because of the discovery of 'illat, and further ensure that a woman still has to practice these traditions in a different way of thinking.

In addition to presenting studies that have been previously carried out by scholars, this paper will also focus on studies related to the ability to develop Islamic law from the point of view of ta'lîl al-ahkâm while at the same time confirming the expansion of other meanings of mahram that have been put forward by previous scholars.

\section{Method}

This research is a research library where the data source comes from reading books and articles that discuss this theme. There are somewhat many articles that have been published on this theme, but with different approaches, research questions, and results, all of which the authors make as references in this paper. The approach taken in this research is the 'illat approach, in which the author uses the al-sibr wa al-taqsimm method to look for legal reasons behind the provisions written in nash about mahram for womentravelers. Overall, the analysis used in this paper is descriptive and comparative. The comparative sides can be seen when the writer chooses one alternative from

7 Yusdani, "Ushul Fikih Dalam Hukum Islam Progresif”, Jurnal Madania, vol. 19, no. 1 (2015), p. 64.

${ }^{8}$ Fadhilatul Maulida and Busyro, "Nafkah Iddah Talah Ba in dalam Perspektif Keadilan Gender (Analisis Terhadap Hukum Perkawinan Indonesia)", Al-Hurriyah Jurnal Hukum Islam, vol. 3, no. 2 (2018), p. 121; Zumrodi, "Pendidikan Sensitif Gender Dalam Islam: Telaah Paragdimatis Dalam Sejarah Intelektual Islam Indonesia", Jurnal Palastren, vol. 8, no. 2 (2015), p. 285.

9 Arsal, Busyro, and Maizul Imran, "Kepemimpinan Perempuan: Penerapan Metode Tafsir Hermeneutika Feminisme Amina Wadud", AL Quds Jurnal Studi Alqur'an dan Hadis, vol. 4, no. 2 (2020), p. 491. 
several available alternatives to find the answer of this research.

\section{Understanding Mahram}

Etymologically, mahram is isim maf'ûl from the root word harama-yahrumu haraman mahramun, which means that which is forbidden. ${ }^{10}$ According to Muhammad Rawâs Qal'ahji, mahram is everything that is forbidden by Allah Swt. " Therefore, everything that is strictly prohibited in Islam is haram. In the terminology of figh, haram is an act that is rewarding if it is abandoned and sin when it is done. However, the mahram that is meant here is not in the above terminology, but mahram in a special terminology which has to do with whether or not someone is allowed to marry another person and other legal consequences.

According to Islamic legal terminology, Hasanain Muhammad al Ma'lûf argues that mahram is a person who is forbidden (to marry) with a woman for a long time because there is a kinship (descent), marriage or because of the existence of a sisterhood relationship. ${ }^{12}$ Another understanding was also put forward by Ibn Qudâmah, according to him, there are two definitions of mahram, namely a husband and someone who is forbidden to marry a woman for a long time due to the existence of a nasab (descent) relationship, or due to other reasons. For example, fathers, sons, siblings who are of the same family or same age as him ${ }^{13}$ and so on. Muhammad Rawâs Qal'ahji also stated about the impossibility of being married for a long time. ${ }^{14}$

From the definition of mahram put forward by the scholars above, there is something that needs to be underlined. According to them, the mahram was only what was forbidden to marry him forever. Of course, in this case someone who is at certain times prevented

${ }^{10}$ Abû Luîs al Ma'lûf, Al Munjid, (Beirut: Dâr al-Masyriq, 1986), p. 33; Mahmud Yunus, Kamus Arab Indonesia, (Jakarta: Hida Karya Agung, 1990), p. 101.

"Muhammad Rawâs Qal'ahji, Mu'jam Lughah al Fuqahâ', (Beirut: Dâr al Nafâ'is, 1998), p. 411.

${ }^{12}$ Hasanain Muhammad al Ma'lûf, Fatâwâ Syar'iyyah wa Buhûts Islâmiyyah, (Mesir: Dâr al Kitâb al Arabiy, 1951), p. 67.

${ }^{13}$ Ibn Qudâmah, al Mughnî..., pp. 6:238.

${ }^{14}$ Muhammad Rawâs Qal'ahji, Mu'jam Lughah..., p. 411. from marrying a woman, such as a husband's sibling, is not included in the mahram category. As a consequence, they cannot be alone together (khalwat) with their brother's wife. Although in their daily life they seem close in terms of kinship, in this case they are not included in the category of mahram in Islam.

Muhammad Rawas Qal'ahji defines that the mahram on the journey is a Muslim man who is sensible, where he can look at the woman and make love to her, namely the husband and the person who is forbidden to marry that woman. ${ }^{15}$ Thus a mahram in marriage is an unlawful person to be married for forever. While the mahram on the way is a person who is lawful in twos and a woman, whether the mahram is due to descent, one-sidedness or marriage and also her husband.

On the other hand, generally people have often equated mahram and muhrim. Muhrim is isim fâ'il from the root word ahrama yuhrimu (haram). Apart from being able to mean someone who is performing ihram, muhrim, as stated by Qal'ahji, is someone who causes it to be forbidden for a woman to marry someone else and the person who looks after her. ${ }^{16}$ In connection with this discussion, the meaning of muhrim is that which is directly related to the discussion of marriage, namely the husband because he causes it to be forbidden for a wife to marry another person as long as she is still married with him and does not include the others. Therefore, it is wrong if a child, a relative or a father, say muhrim for a woman, because they do not make it haram for her to marry someone else. Thus the term muhrim is only appropriate for husband. When a husband accompanies his wife on a trip, then his position is as a mahram who guards and protects his wife. Meanwhile, when he functions as a person who prevents his wife from marrying another person, then he is called a muhrim.

Based on the definition of mahram that has been stated above, in general, mahram is divided into three types, namely; mahram nasab (descent),

\footnotetext{
${ }^{15}$ Muhammad Rawâs Qal'ahji, Mu'jam Lughah..., p. 411

${ }^{16}$ Fu’âd Afrân al Bustâniy, Munjid al-Thullâb, (Beirut: Dâr al-Masyriq, 1986), p. 117; ibn al-Manzhûr, Lisân al 'Arabi, (Beirut: Dâr al-Fikr, 1990), vol. 12, p. 124.
} 
mahram mushaharah (because of marriage) and mahram radha'ah (because they are one-sided). Of these three forms it can also be classified into temporary mahram (muaqqat) and mahram for duration (muabbad). ${ }^{17}$ Mahram nasab and milk can certainly be included in the category of muabbad mahram, but some mahram mushaharah are muabbad and some are muaqqat.

\section{'Illat Studies Related to Mahram's Hadith}

In several Hadiths it is stated that the Prophet PBUH prohibited women from traveling (travelers) unless accompanied by their mahram. At least there are several Hadiths that provide rules on how a woman should go on a journey. In the Hadith narrated by al Bukhârî, there are 4 pieces of Hadith about this with different sanads, including: ${ }^{18}$

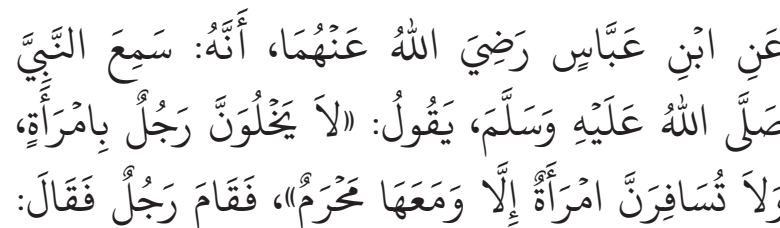

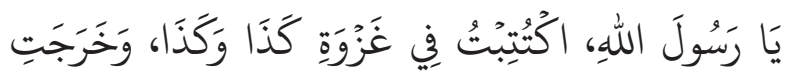

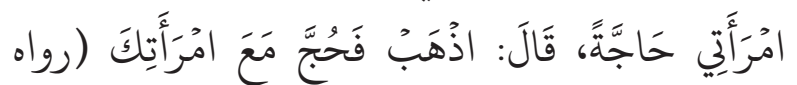

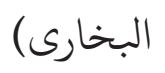

"From Ibn Abbas ra. Heard RasulullahPBUH say:" Do not be a man in twos (khalwat) with a woman and a woman should not go on a safar (journey) unless accompanied by her mahram. Then a man stood up and asked, "O Messenger of Allah, my wife wants to perform the pilgrimage, while I am on duty in war, do I have to accompany her? Rasulullah replied, "Yes, go, accompany your wife to perform the pilgrimage" (Narrated by Bukhârî).

The above Hadith is narrated in various versions by Imâm al-Bukhâri, Muslim, Abû Dâwûd, and others. In the research conducted by Nurun

${ }^{17}$ See Ibn Syihâb al Dîn al Ramlî, Nihâyah al-Muhtâj 'Alâ Syarh al Minhâj, (Beirut: Dâr Ihyâ` al-Turâts al-Araby, 1992), vol. 6, pp. 271-81; Abû Ishâq Burhân al-Dîn Ibrâhîm Muhammad Ibn 'Abdillah Ibn Muhammad Ibn Muflih al Hanbalî, al Mubdi' fî Syarh al Muqni’, (Beirut: Maktabah al--lslâmiy, 1981), vol. 7, pp. 56-79; Wahbah al Zuhayli, al Fiqh al Islâmiy wa Adillatuh, (Damaskus: Dâr al-Fikr, 1989), vol. 7, pp. 138-79.

${ }^{18}$ Ibn Hajar al Atsqalânî, Fath al Bâri Syarh Shahîh al Bukhârî, (Beirut: Dâr al-Fikr, 1991), vol. 6, 250, 553, 392; Abû Zakariâ Muhyi al Dîn al Nawawî, Al Majmû'..., 5:103-10.
Najwah, the Hadith texts regarding the necessity of a woman to be accompanied by her mahram can be ascertained that her authenticity comes from the Prophet PBUH. ${ }^{19}$ Responding to the above Hadith, the Imams of the Schools have commented. Imâm al Syâfi'î said that the obligation to be accompanied by a mahram for women travelers applies to all trips that are not required, such as pilgrimages, tours and so on. If during this journey a woman is not accompanied by her mahram, it means that she has committed an unlawful act, even though in this case several trusted women are appointed to accompany her. However, for compulsory travel, such as the pilgrimage, it is permissible for a woman to be accompanied by several other women as her mahram. Even if security is suspected, it is permissible for women to go alone. ${ }^{20}$

Meanwhile Ahmad ibn Hanbal said that it is not obligatory for women to travel (safar) in order to perform the haj pilgrimage without being accompanied by a mahram or her husband. ${ }^{21} \mathrm{~A}$ woman who is still on the pilgrimage without being accompanied by her mahram means that she has committed an unlawful act. Thus, mahram is something that is very urgent for women in traveling, so that something that is basically obligatory may turn out to be no longer obligatory.

Contemporary scholars, including Yûsuf alQaradhîwi, said that in principle a woman should be accompanied by a mahram or her husband on the pilgrimage. The basis for this obligation are several traditions of the Prophet PBUH which, among others, were narrated by Abû Hurairah (d. 57 H), ibn 'Abbâs (d. 68 H), ibn Umar (d. 74 H), and Abû Sa'îd al-Khudri ( w. 84 H). ${ }^{22}$ Although these Hadith texts are different from one another, they

${ }^{19}$ Nurun Najwah, "Fenomena Mahram Haji di Indonesia", Jurnal Asy-Syir'ah, no. 2 (2008), vol. 42, p. 324.

${ }^{20}$ Ibn Syihâb al Dîn al Ramli, Nihâyah al Muhtâj Ila Syarh al-Minhâj, (Beirut: Dâr al-Ihyâ' al Târîkh al 'Arabi, 1992), vol. 3, p. 250; Imam Ibnu Hajar, "Reinterpretasi Hukum Larangan Bepergian Tanpa Mahram Bagi Perempuan”, Al-Manahij: Jurnal Kajian Hukum Islam, vol. 6, no. 1 (2012), pp. 146-7.

${ }^{21}$ Ibn Qudâmah, al Mughnî..., pp. 3: 235.

${ }^{22}$ Yûsuf al-Qaradhâwi, Min Hadyi al-Islâm Fatâwa Mu'âshirah, (Manshûrah: Dâr al-Wafâ' al-Thabâ’ah wa al-Nasyr wa al-Tawzî', 1994), vol. 1, p. 350. 
have the same meaning, namely the prohibition of women traveling alone. This is intended to safeguard the good name and honor of women, in addition to protecting them from the crimes of other people, robbers, and wild animals, especially when the woman passes through a dangerous environment such as the desert or a situation in a lonely and unsafe area.

In one of his statements Yûsuf al-Qaradhâwî wrote that traveling on this day is not the same as the previous times which were full of dangers because they had to pass through the desert, were intercepted by robbers, and so on. Even when traveling, they use transportation means that contain many people, such as ships, planes, and large and small public buses that pass through several places. This raises self-confidence and eliminates worries (fear) for women, because at that time she was not alone in one place. Therefore there is no obstacle for a woman to go on Hajj in this calm and safe atmosphere. ${ }^{23}$

Thus, it can be understood that according to Yûsuf al-Qaradhâwî, the pilgrimage made by women today is safe, unlike the previous pilgrimage which was full of dangers. This is because traveling now uses the means of transportation that already have safety (security) that did not exist in the past, and usually contains many people, such as ships, airplanes, and public buses which do not need to be worried about in terms of safety. Therefore the pilgrimage made by a woman alone for her present condition is permitted without her mahram accompanying her.

The discussion of a legal provision, in this case is a mahram for women pilgrims for women, is certainly inseparable from the factors or reasons behind it. The reason referred to here is the 'illat of the ordinance. In their studies, the scholars did not explicitly mention what 'illat is from this decree, but from what they conveyed it can be concluded that' illat exists, like the sign of al-Shafi'i (d. 204 H) which states that the existence of mahram is to create a sense of security for women. ${ }^{24}$ Likewise,

${ }^{23}$ Yûsuf al-Qaradhâwi, Kaifa Nata'âmal ma'a al-Sunnah alNabawiyah, (Kairo: Dâr al-Syurûq, 2002), p. 149.

${ }^{24}$ Nawawî, Al Majmû' Syarh al Mudhadzdzab, 7: 86; Wahbah al Zuhayli, al Fiqh al Islâmiy wa Adillatuh, (Damaskus: Dâr al-Fikr, what is implied in the statement of Ahmad ibn Hanbal $(\mathrm{d} .241 \mathrm{H})$ which does not mention the issue of safe or not, but only focuses on women who practice safar. ${ }^{25}$ Thus it can be understood, that according to Ahmad ibn Hanbal (d. $241 \mathrm{H}$ ), safar itself seems to be the 'illat of legal determination. Likewise with what is hinted by Abu Hanifah (d. 150 H) and ibn Hazm (d. $438 \mathrm{H}$ ). From this description, the nas (Hadith) regarding mahram for women travelers does not show or is not accompanied by an explicit mention of 'illat, so there is a possibility for an interpretation to determine 'illat because it is closely related to worship activities carried out by a woman.

Based on the study of various kinds of 'lllahat and the procedures for finding it, some of them are manshûshah (mentioned explicitly in the text) and some are mustanbathah (try to find them with deep thought). So 'illat mahram for womenpilgrims is included in the mustanbathah category because it is not clearly found in the text so it takes serious effort to find it, with the consideration that there must be munâsabah (harmony) between the 'illat and the wisdom to be aimed.

Based on the conclusions drawn from the statements of the ulama, the most appropriate method in determining the 'illat of mahram law in this matter is through al sibr wa al taqsîm, which is to collect a number of characteristics that we think can be used as a reason for determining the law then limiting to a trait that is considered more appropriate. The latter characteristic was later chosen as illat in the determination of the law. ${ }^{26}$ On the other hand, the nature of munâsabah (in accordance with the purpose of establishing the law) also needs to be considered because it cannot be categorized as 'illat if it does not contain munâsabah. ${ }^{27}$ Therefore, the characteristics that

1989), vol. 3, p. 36; Syihâb al Dîn Ahmad ibn Hajar al Haitamî al Syâfî̂, Hawasy Tuhfah al Muhtâj bi Syarah al Minhâj, (Mesir: Mustafa Muhammad, [tth]), vol. 4, p. 24; 'Abd al Hâmid al Syarwânî, Hawâsy 'Ala Tuhfah Li al-Muhtâj, (Beirut: Dâr Ihyâ' al-Turâts al-Araby, [tth]), vol. 2, p. 358.

${ }^{25} \mathrm{Abd}$ al Qadîr ibn Umar al Syaibâni wa Ibrâhîm ibn Muhammad Dhiwânî, Al-Mu'tamad fî Fiqh..., pp. 1: 327.

${ }^{26}$ Busyro, "Using Zakâh for The Establishment Of Islamic Centers And Maqâșid Al-Syarî‘ah's Relativities", Al-Risalah Forum Kajian Hukum Dan Sosial Kemasyarakatan, vol. 19, no. 1 (2019): 81.

${ }^{27}$ Busyro, "Eksistensi 'Illat dalam Mengukuhkan Teks Hadis- 
have been collected will also be seen from the side of munâsabah.

After careful examination there are a number of characteristics which seem to underlie this provision; first, safar (journey) itself; second, the fear of slander; and third, security for women when traveling. The author will analyze one by one these properties in accordance with the provisions of the determination of an 'illat.

The first is the safar (journey) itself. The determination of safar as 'illat when connected with the requirements 'illat that has been stated can be analyzed as follows:

1. In terms of clarity (zhâhir) this quality. Here safar seems to be a zhâhir (obvious) quality already. This is seen from the textual side of the Hadith about the mahram for womentravelers. But about what kind of safar and how many days is it categorized as safar? This is where the scholars differ. However, of the many Hadiths about mahram for women travelers, there is one thing that needs to be known, that the difference in the size of the distance and travel time is not a limitation. At least this is what was stated by al Nawawî (d. $864 \mathrm{H}$ ) when giving sharah to the Shahîh Muslim book. ${ }^{28}$ The difference is caused by differences in the difference between the person asking the question and the place to be directed. According to al Nawawî (d. $864 \mathrm{H}$ ), one of the traditions of several traditions about this, as contained in the book Shahîh Muslim, removes these restrictions, namely the Hadith narrated by ibn 'Abbâs: 29

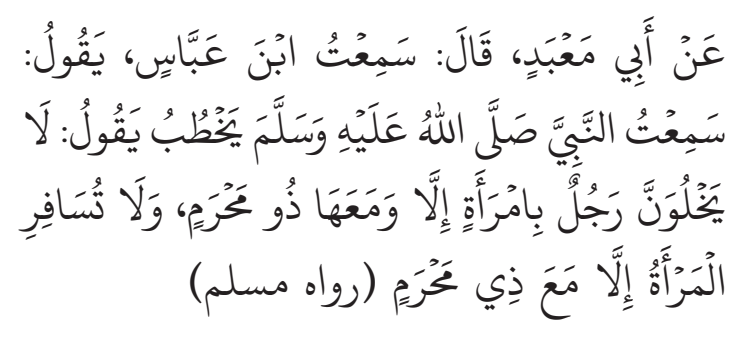

hadis Ru'yat al-Hilâl dan Fungsinya dalam Pengembangan Hukum Islam", Al-Ahkam, vol. 28, no. 2 (2018), pp. 171-2.

${ }^{28}$ Abû Zakariâ Muhyi al Dîn al Nawawî, Shahîh Muslim Bi Syarh al Nawawî, (Beirut: Dâr al-Fikr, [tth]), vol. 5, p. 103.

${ }^{29}$ Abû Zakariâ Muhyi al Dîn al Nawawî, Shahîh Muslim ..., pp. 5: 109.
"From Abi Ma'bad, I heard ibn 'Abbâs ra say," I heard Rasulullah PBUH say in his sermon, "Don't be a woman alone with a man without being accompanied by her mahram and don't do safar without being accompanied by her mahram". (Narrated by Muslim)

This condition covers all forms and distances of travel and is very clear and tangible and can be understood by the human senses. Thus safar as a trait meets the first criteria of the 'illat requirement, namely washfan zhâhiran (clear character).

2. In terms of whether or not this characteristic can be measured and applies to all people (washfan mundhabithan), here safar characteristics can certainly be measured and also generally applies to everyone who travels. Therefore even this criterion has been fulfilled by this characteristic.

3. In terms of harmony with the wisdom of law (washfan munâsiban li al hukm), then here it seems that making safar solely as 'illat is very difficult to realize the wisdom of a law. This will be very pronounced when dealing with modern times which are full of various transportation advancements and given the high costs incurred to make such a trip. It is a difficult condition if a woman has to be accompanied by her mahram wherever she goes. Like a womenstudent studying abroad for example. During the journey until school finishes (graduation), of course, he must always be accompanied by his mahram because as long as he does not intend to stay in the destination country, his position is still as a traveler. Likewise with business trips, tours and so on. This means that if he has to be accompanied by his mahram wherever he goes, it means he has to spend at least two people (him and his mahram). If this legal provision is enforced absolutely, it is tantamount to hindering a woman's activities, including hindering their activities to gain knowledge in other countries. Maybe for people who have large funds (conglomerates), whatever the cost will not be a problem, but on the other hand it will also be difficult, 
especially for the mahram who will accompany the woman. Therefore, implementing safar absolutely has not been able to realize the wisdom that is to be realized (benefit). Therefore, with absolute provisions like this, the benefits to be achieved and also rejecting things that hinder the benefit are difficult to realize. In addition, the provisions of mahram for women travelers in the Hadith of the Prophet Muhammad are not related to the provisions of the provisions of worship (ta'abbudi), but are more in the nature of social relations which can be ascertained to have their own reasons outside safar. The reason for this particular reason will later produce lessons that will be realized with the stipulation of the law. Thus the author does not see any convincing relevance in determining safar absolutely with the wisdom to be achieved with this legal provision, and of course in this connection safar cannot be made 'illat the inability of women to travel alone without their mahram.

Taking into account the above, on the one hand safar does fulfill some of the requirements of 'illat, but on the other hand, safar alone cannot manifest legal wisdom. In the study of Islamic law, wisdom is something to be aimed at by establishing a law. If a wisdom in the form of benefit and rejecting harmful things cannot be realized, then such legal stipulations need to be reexamined. This is because the estuary of Islamic law is to create maslahah in both worldly and ukhrawi life. ${ }^{30}$

The second alternative about 'illat prohibition of safar for women without being accompanied by a mahram or her husband is worrying about slander. Slander in this case can be in the form of defaming a woman's good name, being accused of being a bad woman or wandering and so on. This form of form is not only bad for the woman concerned, but will damage the good name and honor of her family and hometown. The result is

30 Busyro, "Menyoal Hukum Nikah Misyar Dalam Potensinya Mewujudkan Maqashid al-Ashliyah dan al-Tab'iyah Dalam Perkawinan Umat Islam", Al-Manahij: Jurnal Kajian Hukum Islam, vol. 11, no. 2 (2017), p. 217. even more severe is disruption in relationships in household and community relations.

In this connection it can be exemplified by the slander that afflicted the ummul believers Aisyah ra $(\mathrm{d} .57 \mathrm{H})$. The story begins when Aisyah took the turn to go with the Prophet Muhammad in a battle as a rear unit to care for wounded soldiers. After the war ended with victory on the part of the Muslim army, the Islamic troops were ready to return to Medina. As the Prophet's wife, Aisyah was welcome to enter the scoop. Before a second was lifted Aisyah suddenly felt like she was going to waste herself. When he returned to his dimmer he found the necklace that was usually tied to his neck was missing. He returned to the toilet and found it there. The people did not expect Aisyah to go away and they had closed the shovel and put it on the camel's back. Then the troops started off. Of course Aisyah was surprised when she found herself abandoned. While waiting for the troops to return to pick her up, Aisyah fell asleep. It was at that time through the Prophet's friend, Shafwan ibn al Mu'athal al Salmi. It was the custom for Shafwan to walk behind the troops to pack items that had fallen or were lost and returned to their owners. Shafwan was very surprised to see Aisyah ra. Finally he ordered Ayesha to get on his camel and he himself led her. This incident shocked the Muslims and exposed various kinds of accusations/slanders to Aisyah and Shafwan. In this case, the hypocrites took more part in discrediting Aisyah. As a result, Aisyah's good name was tainted and even disturbed her relationship with Rasulullah PBUH. Finally, Allah Swt sent down His revelations, as contained in Surah al- Nûr [24]: 11 and Surah Yûsuf [12]: 18 which clears Aisyah's good name and criticism of those who accuse her without any concrete evidence. This incident is better known as the Hadith al-ifk (fake news). ${ }^{31}$

The story above gives an understanding, that a woman's journey without being accompanied by a mahram or her husband has the potential to cause

31 Jabir Asy Syal, Profil di Balik Cadar Kisah Perempuan dalam Al-־Quran. Judul asli, Qishash al Nisa' fi Alquran al Karim, (Jakarta: Pustaka Utama Grafiti, 1993), pp. 93-103. 
slander and disrupt family and social relations. But whether or not the fear of slander arises as an alternative to 'illat will be analyzed by relating it to the requirements of 'illat.

When viewed from the point of view of clarity of character (zhâhir), the emergence of slander cannot be categorized as a real and clear characteristic or can be observed with human senses. This is because the emergence of slander is a trait that is difficult for humans to observe and avoid. Slander is sometimes only shown by changing one's attitude towards others, such as cynicism or staying away from social interactions. Measuring and seeing someone's attitude is a difficult thing. What is needed as' illat is a quality that is clear, tangible and can be sensed by humans. The emergence of slander as 'illat will only become clear and real when there is a statement and commitment from the whole community, both written and unwritten, that a woman traveling without a mahram or her husband is a bad woman. However, the statement statement above has not been found in real terms. Therefore the emergence of slander is still a mental state that is difficult to identify by the human senses. Of course in this case defining it as 'illat cannot fulfill the conditions of the first “illat', namely washfan zhâhiran (a clear, tangible and sensable character by humans).

In addition, the emergence of slander when it is related to a woman's journey without a mahram or her husband can not be measured with certainty and does not apply to everyone (washfan mundhabithan). This is due to the different conditions and situations of the woman's journey. Indeed, there are women whose reputation has been tainted with various consequences by making the trip, but there are also many women who do not get any slander by traveling alone. In other words, the emergence of slander may be experienced by some women and some conditions, such as the story of Aisyah above, but not experienced by some women and other conditions. For example, when Aisyah went to perform the pilgrimage to Mecca after the death of the Prophet Muhammad without being accompanied by her mahram, it did not cause any slander. Perhaps this is why classical and contemporary figh ulama did not mention in their discussion when talking about the causes of prohibition of women traveling alone. In addition, the Hadith of the Prophet Muhammad, PBUH was not found which explicitly led to the fear of slander if women were alone.

According to the author, he does not mention the concern about the emergence of slander as a trait that encourages legal determination because the emergence of slander refers more to the inner atmosphere or feelings that are not directly related to the physical and human senses, while the study of figh scholars generally focuses more on things that are clear, real and directly related to human senses or physical. That is why the legal establishment for a case focuses more on something zhâhir (can be sensed) and not on something that is a mental state (psychological condition). Like a voluntary attitude in buying and selling that cannot be observed because it is an inner (psychological) mood. In order to realize this voluntary attitude, consent and qabul are stipulated, because by this one's willingness can be observed and sensed. Based on that, the fear of slander is not a mundhabith characteristic, therefore he cannot fulfill this second condition of 'illat.

Although the two conditions above cannot be fulfilled, these characteristics seem to have relevance to the maslahah that is about to be realized, namely the preservation of women from slander and slander that may arise as a result of the journey she takes without a mahram or her husband (washfan munâsiban). If this characteristic is used as a reason for establishing the law, then one side of the benefit can be realized. However, it should be noted that the fear of slander was not supported by qarinahqarinah, both in terms of social culture at that time (when the Hadith was delivered) and the explanation of the Prophet Muhammad which referred to it. The only qarinah that exists is the story of Aisyah above, but Allah Swt has cleared her name accompanied by criticism of those who discredited her. In addition, Allah Swt also criticizes those who accuse good and good women of committing obscene acts (zina) without presenting four male witnesses who 
actually witnessed the incident with their own eyes (Q.S. Al-Nur [24]: 4). Since slander often arises because of news from other people, Allah Swt also warns not to just believe the news without investigating the truth (Q.S. Al- Hujurat [49]: 6). One thing that can be understood in this case is that it is not easy to slander someone unless there is direct evidence and witness of the incident. This also prohibits believers from defaming the good name of others because it will have a bad effect on themselves and their families. Even in this connection, there are many prohibitions on the prohibition of disclosing the shame of others accompanied by threats of threats to those who do so.

Thus the concern about the emergence of slander, although it can create benefit, it is not strongly suspected as a trait that encourages the establishment of law. Of course this alternative trait cannot be defined as 'illat prohibiting women from making the pilgrimage alone without being accompanied by a mahram or her husband. This condition will be even more pronounced if it is related to the journey of modern-day women who rarely even get any slander when they travel.

The third is security for women on the way. ${ }^{32} \mathrm{He}$ made security an alternative to 'illat because there are several possible qarinahs (signs) indicating it. Among the possible qarinahs are geographic conditions and the remnants of jahiliyah that were still present at the time the Hadith was pronounced. As it is known that the Arabian Peninsula is mostly composed of barren, arid deserts and many places of solitude from humans so that not only women, a man is very worried about traveling alone in such conditions. Meanwhile, if you look at the atmosphere and behavior of the ignorant community, it is no stranger that during the jahiliyah era, women were the objects of male deception and cruelty. They are deprived of their rights, their property is controlled, it is forbidden to inherit and after divorcing or the death of their husbands, they are not allowed to marry a man they like, but

${ }^{32}$ Hajar, "Reinterpretasi Hukum Larangan Bepergian Tanpa Mahram Bagi Perempuan”, pp. 150-1. inherit like property or a vehicle. ${ }^{33}$ On the other hand, originating from the nomadic life system, the Arabs have a warlike temperament and make raids. So strong is that temperament that fighting has become a kind of entertainment and fun. They take warfare and bloodshed lightly so that even a small event can provoke a big war. According to Abu al Hasan Ali al Nadwi, the whole peninsula was beset by constant tensions. People don't know when he was robbed or killed. A person can be kidnapped from the caravan on the way. The things mentioned above, although it was a general condition of the era of ignorance, of course it did not completely disappear when the Prophet PBUH broadcast Islamic dakwah. The inconvenience of traveling is of course also triggered by the continuous tension between Muslims and the Quresys of Mecca, Medina Jews and other enemies of Islam, especially after the Prophet PBUH moved to Medina. Coupled with the very simple means of transportation at that time, namely camels, horses or donkeys. In fact, it is not uncommon for the trip to be done on foot. Therefore, it is natural that there is a concern that women traveling alone will experience dangers, so the Prophet Muhammad (peace and blessings of Allah be upon him) forbade women to travel alone without a mahram or her husband.

Another thing that can be used as a qarinah for this security characteristic is the Hadith of the Prophet Muhammad narrated by al-Bukhârî from Adi ibn Hatim:

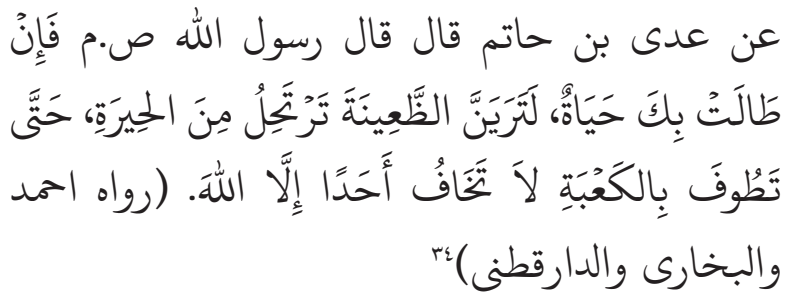

"From Adi bin Hatim said, the Prophet PBUH had said," If you live long you will see a woman

${ }^{33}$ Abû Hasan Ali al Nadwi, Islam Membangun Peradaban Dunia, judul asli; Ma dza Khasira al 'Alam bi Inkhithat al Muslimin, terjemahan M. Ruslan Shiddiqi (Jakarta: Pustaka Jaya dan Djambatan, 1988), p. 95.

${ }^{34}$ Muhammad ibn Ismâ'îl Abû 'Abdillâh al-Bukhârî, Al-Jâmi' al-Musnad al-Shahîh al-Mukhtashar Min Umûr Rasûlillâh SAW Wa Sunanuh Wa Ayyâmuh, (Damaskus: Dâr Thûq al-Najâh, 1422), vol. 4, p. 197. 
riding a horse going from Hirah (Irak) to thawaf (performing the haj) in the Ka'bah (Makkah) with a feeling of not being afraid of anyone except Allah." (Narrated by al-Bukhârî and Ahmad).

In Ahmad's history it is stated that the woman was not afraid even though she was not accompanied by anyone. ${ }^{35}$ This Hadith according to ibn Hazm (d. 438H), As Yûsuf al-Qaradhâwi information, ${ }^{36}$ it is not a denial of the safar provisions for women in the Hadith of the Prophet Muhammad, but reflects the prudence of Islam and the security of its territory in the future, so that there are no more security disturbances that women are worried about. Therefore, the safety factor seems to be emphasized more by Yûsuf al-Qaradhâwi in the signs found from the above Hadith. This means that with this statement Rasulullah PBUH was able to imagine the atmosphere that occurred after he left (died), and furthermore the Hadith suggests that it is true security that underlies this legal provision.

Based on this, if Yûsuf al-Qaradhâwi's opinion is analyzed by studying the simple requirements of 'illat, then security as a trait, although it cannot fulfill one condition, namely a clear character (washfan zhâhiran) that can be observed by the human senses, however according to Yûsuf alQaradhâwi, it can be strongly suspected as 'illat who motivates the establishment of law. This assumption can of course be deduced from the socio-cultural ignorance that still remains to some extent coupled with the continuing tensions between Muslims and the infidels of Mecca, Jews and other enemies of Islam at that time and the geography of the Arabian Peninsula which was less friendly to traveling alone, and there is also a hint of the latter Hadith. But this view must of course be thoroughly analyzed in light of the other 'illat terms.

The next requirement is washfan mundhabithan (relatively measurable properties). This means that these characteristics can be ascertained and are

${ }^{35}$ Ahmad ibn Hanbal, Musnad Imâm Ahmad, (Beirut: Dâr al-Fikr, [tth]), vol. 30, p. 196.

${ }^{36}$ al-Qaradhâwi, Min Hadyi al-Islâm Fatâwa Mu'âshirah, 1: 353; al-Qaradhâwi, Kaifa Nata'âmal ma'a al-Sunnah al-Nabawiyah, p. 149. generally accepted for all people. Security as 'illat' prohibits women from doing safar alone even though it is obtained by zhanni, but it can be strongly suspected (although not mundhabith). This is supported by the internal condition of women who are weak creatures to defend themselves in the face of danger. Even though there are women who are strong, able to take care of themselves, even more than men, this only applies to certain women. But in general, women are weak creatures and need help and protection from others.

Apart from that, the condition of Arabia, both in terms of geography and in terms of society, which still leaves the civilization of civilization and the traditions of jahiliyah are still very worrying to let a woman go on a journey alone. In line with Aramdhan Kodrat Permana, it is the safety factor of women which is a characteristic that can lead to strong suspicions (mazhinnah) that has prompted Rasulullah PBUH to issue a requirement that women be accompanied by their mahram on trips. ${ }^{37}$ From this perspective, security for women cannot be measured and is generally accepted. This means that the conditions of travel by each woman are of course different from one another. Therefore, if it is followed the requirement of 'illat which has been stated earlier, then the nature of mundhabith (certain) does not apply in this security characteristic. Atho Mudzhar's discovery of 'illat security as a social reason underlying the birth of a law, as quoted by Maulidi. According to Atho, law [including Islamic law] is part of a cultural and social phenomenon, so that it is not sufficient to understand law with a mere textual understanding, but it must be combined with contextual understanding by considering the culture and social aspects that develop in society. Because after all the law and society have a reciprocal relationship. ${ }^{38}$ This kind of thinking model seems to be the same as the hermeneutic concept proposed by Fazlur Rahman, namely by examining the historical situation and problems

37 Aramdhan Kodrat Permana, "Mahram Pada Safar Perempuan Dalam Tinjauan Sosiologis Menjembatani Realitas Muslim Klasik dan Kekinian”, Musawa, vol. 9, no. 1 (2010), p. 108. ${ }^{38}$ Maulidi, "Paradigma Progresif dan Maqashid Syariah: Manhaj Baru Menemukan Hukum Responsif”, Asy-Syir'ah Jurnal Ilmu Syari'ah dan Hukum, vol. 49, no. 2 (2015), p. 257. 
in which the statement arises, ${ }^{39}$ which ultimately finds the historical reasons behind the birth of a provision. Thus, security as a legal reason has a clear relationship with the legal material conveyed by the Prophet PBUH. Especially at that time, according to ibn Hazm, the context had to do with the atmosphere of war. This is evidenced by the Hadith information that one of the companions complained to the Prophet that he was being assigned to various battlefields, but that his wife wanted to perform the pilgrimage. Of course, it cannot be denied that the atmosphere of war is closely related to the unsafe road to be taken.

Another requirement that is no less important than the two conditions above is the harmony between 'illat and the wisdom that the legal provision is trying to achieve (munâsib li alhukm). Defining security as' illat when viewed contextually has reasons that can be justified because the prohibition is of course to safeguard and protect women from unwanted things. With this prohibition, women are not allowed to travel alone. If this is still done, it is very worried that there will be dangers that will befall him. Eliminating danger (mafsadah) is a lesson that is to be achieved by a legal provision at the same time will also be able to realize benefit. ${ }^{40}$ It seems that this security factor actually motivated the Prophet Muhammad to prohibit women from traveling alone. Thus munâsib as one of the conditions 'illat accumulates with this quality.

Taking into account the analysis of 'illat above, it can be concluded that the safety factor is a logical reason that motivates the enactment of the law prohibiting women from traveling alone. Of course, in this case the safety factor, as mentioned above, is not an absolutely certain characteristic because not all women who travel alone will experience dangers that threaten themselves, their property and their honor. However, even so, the realization of security on the way can give

${ }^{39}$ Ahmad Fawaid, "Reinterpretasi Hadis Tentang Mahram (Pendekatan Hermeneutika)", Jurnal Nur El-Islami, vol. 3, no. 1 (2016), p. 178.

${ }_{40}$ Busyro, "Bom bunuh diri dalam fatwa kontemporer Yusuf al-Qaradawi dan relevansinya dengan maqâshid alShari'ah", IJTIHAD Jurnal Wacana Hukum Islam dan Kemanusiaan, vol. 16, no. 1 (2016), p. 90. rise to strong allegations that have motivated the enactment of the law.

It is in this context that some of the ushûl figh scholars have discussed the possibility of making wisdom as 'illat of law. Ibn Taymiyyah $($ d. $728 \mathrm{H})$ does not require the existence of a mundhabith (relatively measurable) character in 'illat, but focuses more on the harmony between the stipulation of a law and the wisdom to be achieved (al-washf al-munâsib), and that wisdom is what motivate the enactment of the law..$^{41}$ Likewise with al-Syâthibî (d. $790 \mathrm{H}$ ) who interpreted 'illat with the benefit of the benefits to be manifested and rejection of mafsadah. The concept of 'illat al-Syâthibî is closely related to the mâqâshid alsyarîa which he popularized so that with such an understanding of' illat it will be able to form a dynamic Islamic legal mechanism because 'illat is generally the mâqâshid al-syarî'ah. alone. ${ }^{42}$ That is why al-Syâthibî gave the meaning of 'illat which was different from most of the other ushul scholars. 'Illat in the understanding of other scholars, for al-Syâthibî is al-sabab. Meanwhile, wisdom in understanding jumhur, for al-Syâthibî is 'illat itself. Therefore, if it is related to other examples, such as the ability of qashar praying for travelers, the safar which is stated by the jumhur scholars as 'illat, for al-Syâthibî (d. $790 \mathrm{H})$ it is none other than al-sabab. While masyaqqah which is wisdom in the view of the jumhur of scholars, for al-Syâthibî masyaqqah it is 'illat which motivates the establishment of the law itself. Lebib far he said that mundhabith (can be measured) or not that nature, if he is able to realize the goal of law, then that is the 'illat.

Al Sa'diy in his book Mabâhits al 'lllah fî al Qiyâs' inda al Ushûliyyîn, admits that wisdom is indeed a hidden nature and its existence cannot be ascertained so that it causes different scholars to position it as the reason for the determination of law ('illat). However, according to him, a quality that gives rise to a strong suspicion of

${ }^{41}$ Muhammad Abû Zahrah, Ibn Taimiyyah Hayâtuhu wa Ashruh Arâ'uh wa Fiqhuh, (Kairo: Dâr al Fikr al Arabiy, [tth]), p. 476.

42 Abû Ishâq Ibrâhîm ibn Mûsâ al-Lakhmi al-Gharnathi al Syâthibî, al-Muwâfaqât fî Ushûl al-Syarî’ah, (Mesir: Maktabah al-Tijâriyah al-Kubrâ, [tth]), vol. 1, p. 265. 
the existence of that nature (mazhinnah) can already be said to be 'illat, such as mazhinnah (something that raises a strong suspicion) that the presence of masyaqqah in traveling is' illat which motivates the law of qashar prayer. ${ }^{43}$ Even al Baidhawi in this case allows 'illat 'with wisdom absolutely because wisdom is a munâsabah (in accordance with the purpose of law). If it is not permissible to 'illat with wisdom ', it means that it is not allowed to 'illat with munâsabah characteristics. Therefore it is in line with the scholars above, according to him [in the case of qashar permissibility for travelers] this ability is not due to masyaqqah alone, but because of the existence of safar. ${ }^{44}$

From the statement of the ulama's statement above, along with the examples they put forward, it can be concluded that it is permissible to do mercy with wisdom on the condition that there is a mazhinnah (a trait that gives rise to a strong suspicion) that it is capable of realizing legal objectives (realizing benefit and avoiding harm). However, before seeing this wisdom, we must also look at the main factors in determining the law. So in the example above, safar is the main factor (in understanding jumhur safar that is mazhinnah) and this must be realized before seeing the masyaqqah. This means that masyaqqah solely without safar cannot be used as a reason for stipulating the law of permissibility of qashar prayer, it means that solely security without safar also cannot be used as a reason for stipulating law

Observing this way of thinking the writer sees a meeting of opinion between groups that allow 'mercy with this wisdom and groups that oppose it. At least this conformity can be seen in making the main factor (safar) something that must be present before looking at the masyaqqah factor. This is in line with the thought of Jasser Auda, a figure of Contemporary Islamic Law, who said that wisdom is a secondary reason, while 'illat is the benefit that is aimed at by the makers of sharia

43 'Abd al Hâkim 'Abd al-Rahmân As'ad al Sadiy, Mabâhits al 'Illah fî al-Qiyâs 'Inda al-Ushûliyyîn, 1st edition (Beirut: Dâr al Basâ’ir al Islâmiyyah, 1987), p. 106.

44 'Abd al Hâkim 'Abd al-Rahmân As'ad al Sadiy, Mabâhits..., pp. 112-3. or is a strong conjecture that the mujtahid found as the main goal of a law. ${ }^{45}$

If it is related to the existence of a mahram for women pilgrims, which is security for women, then the next step is to determine and again question the 'illat; whether 'illat is still valid or still exists today so that the law is still as it was, or it is appropriate that there is a change in law because it is possible that the underlying 'illat has ceased to exist (changed) as Ushul's rule says: "The law ranges (changes) according to with 'illat, both in realizing and in eliminating it. "However, one thing that needs to be emphasized is that this rule is not intended for original cases but for furu cases where the law will be sought. This is in accordance with the affirmation of Muh. Nasiruddin, that legal development through the method of ta'ilil al-ahkâm it is not intended to ignore the passage, but to maintain the continuity and permanence of Islamic texts. ${ }^{46}$

For now, a careful study of whether or not the 'illat of law underlies the law exists. One thing that must be held is that the law never changes from what it used to be, it's just that whether it is appropriate to apply or not, this is where ijtihâd tathbîqî (studying the appropriateness or inappropriate application of a law and how to apply it), so that in the end it can realize the objectives of Islamic law. to realize benefit. To connect the two conditions (the condition when the nas is pronounced with the present condition) a study approach is also carried out on 'illat tasyrîi ('illat which motivates the formation of law) by relating it to the current context.

As has been witnessed, advances in the world of transportation / transportation make a person who is going to travel far no longer need to walk, ride a camel, horse, donkey and so on, as was the case in the lifetime of the Prophet Muhammad. The long journey at that time had to pass through a lonely place, through the barren desert coupled with the many camp camps of criminals and thieves, so for today it is not so

45 Muh. Nasiruddin, "Ta'lil al-Ahkam dan Pembaruan Ushul Fiqh”, Jurnal Al-Ahkam, vol. 15, no. 1 (2015), p. 24.

${ }^{46}$ Muh. Nasiruddin, "Ta'lil al-Ahkam ..., p. 22. 
found. Humans traveling have used airplanes, cars, trains, ships and so on. From each of these vehicles carrying or carrying tens or even hundreds of passengers, automatically the worry of traveling alone is felt no longer. In fact, the fatwa of the ulama which allows women to do the pilgrimage alone on the grounds that 'illat is no longer present in the journey itself, seems acceptable on the one hand. But on the other hand, this conclusion will of course ignore the textual text, and this still needs to be criticized.

If you look at the situation on a vehicle, such as an airplane, then it is true that the danger that might befall a woman is nothing to worry about. However, the problem will be different when you get off the vehicle, whether when the vehicle stops for a while or when it reaches the last stop (terminal, port or airport). Of course from this last stop the travelers will scatter according to their respective goals. This is where the dangers that are feared to befall women may occur and may not occur according to the conditions of each region.

The information that has developed so far (based on data obtained from some Indonesian pilgrims) is that there are still dangers, kidnappings and even rape and so on, experienced by women pilgrims in Saudi Arabia. This shows that for this area the concern still remains. As a consequence, the law is still enforced as before, namely the obligation for a woman to be accompanied by her mahram. However, because not all women pilgrims have a mahram, the opinions of Imâm al Syâfî̂ (w.204 H) and Imâm Mâlik (w.179 H) need to be considered because they allow some women to become mahrams in performing the pilgrimage. This is because the pilgrimage is an obligation and means of jihad for women. On the one hand, the existence of several women as mahrams can provide security for others, while on the other hand the obligation of Hajj can be fulfilled. Therefore, this opinion has found the best alternative in practicing the two opposing provisions (ta'ârudh), namely the obligation to have hajj on the one hand and the prohibition of traveling without a mahram who will protect and protect on the other. The concept of care and protection is permissible without violating other provisions, so it is possible that the maintenance is carried out by women, that is, in a collective or group manner so that they may avoid danger. ${ }^{47}$

From the above discussion, it turns out that the meaning of mahram in the opinion of Imâm Mâlik and Imâm al-Syâfi'î is not only limited to men who are haram to marry, but also to other women. This is basically not an exaggeration because mahram is translated as someone who is haram to marry, and a woman with a woman is someone who is forbidden to marry. This is reinforced by another qarinah when the Prophet PBUH prohibited a man from having visits with a woman, if they were individuals who according to the provisions were allowed to marry. On the other hand, the Prophet never prohibited seclusion for people who were prevented from marrying each other. Thus the opinions of Imâm Mâlik and Imâm al-Syâfi'î have developed a broad meaning of mahram for anyone, both male and female, who cannot marry respectively.

The discussion that has been put forward shows that there is still a need for a woman to be accompanied by her mahram in making the pilgrimage, even though from among the women themselves to look after each other. This is to realize and ensure the realization of security for them. Of course, with this conclusion there is no longer any obstacle for a woman to carry out their pilgrimage as well as their jihad. This conclusion is drawn of course from a review of the existence of 'illat of law and its relationship with the wisdom to be achieved by law and also the development of the meaning of mahram which has been put forward by the scholars. Apart from that, it also rests on an understanding of the objectives of Islamic law which will preserve religion, human spirit, honor / descent, reason and property. ${ }^{48}$ Thus looking for 'illat of law in the Hadiths of the Prophet PBUH regarding mahram

47 Aramdhan Kodrat Permana, "Mahram ..., p. 108.

${ }^{48}$ Eko Saputra and Busyro, "Kawin Maupah: An Obligation To Get Married After Talak Tiga in The Tradition of Binjai Village in Pasaman District A Maqashid al-Syari'ah Review", Qudus International Journal of Islamic Studies, vol. 6, no. 2 (2018), pp. 191-2. 
for womentravelers does not mean wasting the text, but rather understanding the soul and spirit contained in it to apply it at this time. At least the textual provisions of the text are not ignored, but are turned (ta'wil) to meanings that do not deviate too far from the textual provisions.

\section{Conclusion}

Based on the study of 'illat about mahram and the purpose of the study of 'illat itself, then the study of 'illat should not omit the provision of nash textually. The legal discovery methodology should be dedicated to strengthening the statements that have been conveyed by the Prophet PBUH and trying to adapt and develop their meaning so that they can be applied at this time. By conducting a study of 'illat, in principle the factor of safety is the mazhinnah (strongly suspected) that motivates the issuance of travel regulations for a woman who must be accompanied by a mahram or her husband. Even so, imposing the absolute safety factor is potentially wasteful when the reason is no longer found. Therefore, the discovery of 'illat must also be supported by the broad development of the meaning of mahram, namely people who are forbidden to marry each other, either between a man and a woman or among women. Therefore, other women also become mahrams for other women. This is certainly a solution for a woman to carry out the pilgrimage. On the one hand 'illat of law can already be realized without neglecting nash textually, and on the other hand the development of the meaning of mahram does not deviate from the meaning of the word mahram itself.

\section{References}

Arsal, Busyro, and Maizul Imran, "Kepemimpinan Perempuan: Penerapan Metode Tafsir Hermeneutika Feminisme Amina Wadud", AL Quds Jurnal Studi Alqur'an dan Hadis, vol. 4, no. 2, 2020, [https://doi.org/10.29240/alquds. v4i2.1976].

Atsqalânî, Ibn Hajar al, Fath al Bâri Syarh Shahîh al Bukhârî, vol. 6, Beirut: Dâr al-Fikr, 1991.

Bukhârî, Muhammad ibn Ismâ'îl Abû 'Abdillâh, al-,
Al-Jâmi' al-Musnad al-SHahîh al-MukhtaShar Min Umûr Rasûlillâh SAW Wa Sunanuh Wa Ayyâmuh, vol. 4, Damaskus: Dâr Thûq alNajâh, 1422.

Bustâniy, Fu'âd Afrân al, Munjid al-Thullâb, Beirut: Dâr al-Masyriq, 1986.

Busyro, "Bom bunuh diri dalam fatwa kontemporer Yusuf al-Qaradawi dan relevansinya dengan maqâshid al-Shari'ah", IJTIHAD Jurnal Wacana Hukum Islam dan Kemanusiaan, vol. 16, no. 1, 2016, [https://doi.org/10.18326/ijtihad.v16i1.85103].

, "Menyoal Hukum Nikah Misyar Dalam Potensinya Mewujudkan Maqashid al-Ashliyah dan al-Tab'iyah Dalam Perkawinan Umat Islam", Al-Manahij: Jurnal Kajian Hukum Islam, vol. 11, no. 2, 2017, [https://doi.org/10.24090/ mnh.v11i2.1297].

, "Eksistensi 'illat dalam Mengukuhkan Teks Hadis-hadis Ru'yat al-Hilâl dan Fungsinya dalam Pengembangan Hukum Islam", AlAhkam, vol. 28, no. 2, 2018, [https://doi. org/10.21580/ahkam.2018.28.2. 2352].

" "Using Zakâh for The Establishment Of Islamic Centers And MaqâShid Al-Syarî‘ah's Relativities", Al-Risalah Forum Kajian Hukum dan Sosial Kemasyarakatan, vol. 19, no. 1, 2019.

Dhiwânî, 'Abd al Qadîr ibn Umar al Syaibâni wa Ibrâhîm ibn Muhammad, Al-Mu'tamad fî figh al Imâm Ahmad, Beirut: Dâr al Khair, vol. 1, 1991.

Fawaid, Ahmad, "Reinterpretasi Hadis Tentang Mahram, (Pendekatan Hermeneutika)", Jurnal Nur El-Islami, vol. 3, no. 1, 2016.

Hajar, Imam Ibnu, "Reinterpretasi Hukum Larangan Bepergian Tanpa Mahram Bagi Perempuan", Al-Manahij: Jurnal Kajian Hukum Islam, vol. 6, no. 1, 2012.

Hanafî, Kamâl al Dîn Muhammad ibn al Wâhid al Sayuâsi ibn al Humâm al, Syarah Fath al Qadîr, Beirut: Dâr al-Fikr, vol. 2, [tth].

Hanbal, Ahmad ibn, Musnad Imâm Ahmad, Beirut: Dâr al-Fikr, vol. 30, [tth].

Hanbalî, Abû Ishâq Burhân al-Dîn Ibrâhîm Muhammad Ibn 'Abdillah Ibn Muhammad 
Ibn Muflih al, al Mubdi' fî Syarh al Muqni', Beirut: Maktabah al--ılslâmiy, vol. 7, 1981.

Hazm, Abû Muhammad Ibn Sa'îd ibn, Al Muhallâ, Beirut: Dâr al-Fikr, vol. 4, [tth].

Khair, Faqihuddin Abdul, "Metode Interpretasi Teks-Teks Agama Dalam Mazhab Salafi Saudi Mengenai Isu-Isu Gender", vol. 13, no. 2, 2012.

Ma'lûf, Abû Luîs al, Al Munjid, Beirut: Dâr alMasyriq, 1986.

Ma'lûf, Hasanain Muhammad al, Fatâwâ Syar'iyyah wa Buhûts Islâmiyyah, Mesir: Dâr al Kitâb al Arabiy, 1951.

Manzhûr, ibn al-, Lisân al 'Arabi, Beirut: Dâr alFikr, vol. 12, 1990.

Maulida, Fadhilatul and Busyro, "Nafkah Iddah Talah Ba in dalam Perspektif Keadilan Gender (Analisis Terhadap Hukum Perkawinan Indonesia)", Al-Hurriyah Jurnal Hukum Islam, vol. 3, no. 2, 2018.

Maulidi, "Paradigma Progresif dan Maqashid Syariah: Manhaj Baru Menemukan Hukum Responsif", Asy-Syir'ah Jurnal Ilmu Syari'ah dan Hukum, vol. 49, no. 2, 2015.

Nadwi, Abû Hasan Ali al, Islam Membangun Peradaban Dunia, judul asli; Ma dza Khasira al 'Alam bi Inkhithat al Muslimin, terjemahan M. Ruslan Shiddiqi, Jakarta: Pustaka Jaya dan Djambatan, 1988.

Najwah, Nurun, "Fenomena Mahram Haji di Indonesia”, Jurnal Asy-Syir'ah, vol. 42, no. 2, 2008.

Nasiruddin, Muh., "Ta'lil al-Ahkam dan Pembaruan Ushul Fiqh", Jurnal Al-Ahkam, vol. 15, no. 1, 2015.

Nawawî, Abû Zakariâ Muhyi al Dîn al, Al Majmû' Syarh al Mudhadzdzab, Kairo: Syirkah al-Azhar, vol. 7, [tth].

, Shahîh Muslim Bi Syarh al Nawawî, Beirut: Dâr al-Fikr, vol. 5, [tth].

Permana, Aramdhan Kodrat, "Mahram Pada Safar Perempuan Dalam Tinjauan Sosiologis Menjembatani Realitas Muslim Klasik dan Kekinian", Musawa, vol. 9, no. 1, 2010.

Qal'ahji, Muhammad Rawâs, Mu'jam Lughah al Fuqahâ', Beirut: Dâr al Nafâ'is, 1998.
Qaradhâwi, Yûsuf, al-, Min Hadyi al-Islâm Fatâwa Mu'âshirah, Manshûrah: Dâr al-Wafâ' alThabâ'ah wa al-Nasyr wa al-Tawzî', vol. 1, 1994.

, Kaifa Nata'âmal ma'a al-Sunnah alNabawiyah, Kairo: Dâr al-Syurûq, 2002.

Qudâmah, Ibn, al Mughni, Mesir: Maktabah al Jumhûriyyah al 'Arabiyyah, vol. 3, [tth].

Ramlî, Ibn Syihâb al Dîn al, Nihâyah al-Muhtâj 'Alâ Syarh al Minhâj, Beirut: Dâr Ihyâ' al-Turâts al-Araby, vol. 6, 1992.

Ramli, Ibn Syihâb al Dîn al, Nihâyah al Muhtâj Ila Syarh al-Minhâj, Beirut: Dâr al-Ihyâ` al Târîkh al 'Arabi, vol. 3, 1992.

Sadiy, 'Abd al Hâkim 'Abd al-Rahmân As'ad al, Mabâhits al 'Illah fî al-Qiyâs 'Inda al-Ushûliyyîn, Beirut: Dâr al Basâ'ir al Islâmiyyah, 1st edition,1987.

Saputra, Eko and Busyro, "Kawin Maupah: An Obligation To Get Married After Talak Tiga in The Tradition of Binjai Village in Pasaman District A Maqashid al-Syari'ah Review", Qudus International Journal of Islamic Studies, vol. 6, no. 2, 2018.

Syâfi'î, Syihâb al Dîn Ahmad ibn Hajar al Haitamî al, Hawasy Tuhfah al Muhtâj bi Syarah al Minhâj, Mesir: Mustafa Muhammad, vol. 4, [tth].

Syal, Jabir Asy, Profil di Balik Cadar Kisah Perempuan dalam Al-ᄀQuran. Judul asli, Qishash al Nisa' fi Alquran al Karim, Jakarta: Pustaka Utama Grafiti, 1993.

Syarwânî, 'Abd al Hâmid, al, Hawâsy 'Ala Tuhfah Li al-Muhtâj, Beirut: Dâr Ihyâ' al-Turâts alAraby, vol. 2, [tth].

Syâthibî, Abû Ishâq Ibrâhîm ibn Mûsâ al-Lakhmi al-Gharnathi, al, al-Muwâfaqât fî Ushûl alSyarî'ah, Mesir: Maktabah al-Tijâriyah alKubrâ, vol. 1, [tth].

Ulya, Atiyatul and Maulana, "Penyertaan Mahram Pada Pelaksanaan Haji Dan Umrah”, Refleksi, vol. 15, no. 2, 2016.

Yunus, Mahmud, Kamus Arab Indonesia, Jakarta: Hida Karya Agung, 1990.

Yusdani, "Ushul Fikih Dalam Hukum Islam Progresif”, Jurnal Madania, vol. 19, no. 1, 2015. 
Zahrah, Muhammad Abû, Ibn Taimiyyah Hayâtuhu wa Ashruh Arâ'uh wa Fiqhuh, Kairo: Dâr al Fikr al Arabiy, [tth].

Zuhayli, Wahbah al, al Figh al Islâmiy wa Adillatuh, Damaskus: Dâr al-Fikr, vol. 7, 1989. , al Figh al Islâmiy wa Adillatuh, Damaskus:
Dâr al-Fikr, vol. 3, 1989.

Zumrodi, "Pendidikan Sensitif Gender Dalam Islam: Telaah Paragdimatis Dalam Sejarah Intelektual Islam Indonesia", Jurnal Palastren, vol. 8, no. 2, 2015. 